\title{
Summary in Spanish
}

\section{LA DESCORTESÍA EN CONTEXTOS INSTITUCIONALES Y NO INSTITUCIONALES}

\author{
Silvia Kaul de Marlangeon
}

La presente comunicación compara pautas de descortesía en contextos institucionales y no institucionales. Entre los primeros, considera el del debate político cara a cara y el de la instrucción militar de reclutas. Entre los segundos, escoge el de la poética tanguera de la década de 1920 y uno de interacción de clase media baja del español rioplatense. Los ejemplos seleccionados ilustran los respectivos contextos en que ocurren determinados tipos de descortesía. La diversidad de esos ejemplos constituyó un desafío para la aplicación de los conceptos teóricos.

Desde una perspectiva sociocultural, Bravo (cf. en este volumen y en 1999, 2001, 2002, 2003 y 2004) define para la cortesía las categorías virtuales de autonomía y de afiliación, con contenido variable según la cultura de que se trate.

En Kaul de Marlangeon (2005a) analizamos la descortesía que denominamos de fustigación y que es agresión verbal del $\mathrm{H}$ (ablante) al $\mathrm{O}$ (yente), constituida abrumadoramente por comportamientos volitivos, conscientes y estratégicos, destinados a herir la imagen del interlocutor; para responder a una situación de enfrentamiento o desafío, o con el propósito de entablarla. La gran mayoría de sus actos son directos, pues propenden a asegurar la confrontación en el discurso.

Para su tratamiento introdujimos los conceptos de afiliación exacerbada, entendida como verse y ser visto como adepto al grupo, a tal punto de escoger la descortesía en su defensa, y de refractariedad, definida como la autonomía exacerbada de verse y ser visto como opositor al grupo, porque el que critica, vitupera, arremete, combate, agrede, quiere expresar que está en una actitud refractaria respecto de aquello que suscita su oposición. Estos dos conceptos se corresponden respectivamente con los de afiliación y de autonomía en el seno de la cortesía. La refractariedad es la actitud opuesta a la de afiliación.

La descortesía de fustigación reconoce dos motivaciones esenciales: a) afiliación exacerbada al grupo o b) refractariedad al grupo. Cada una de ellas presenta dos aspectos: Uno defensivo y otro ofensivo. Cuando el $\mathrm{H}$ descortés es adepto al grupo, agrede a su interlocutor porque éste manifiesta desde gran autonomía hasta oposición al grupo: Hay simultáneamente, por parte del $\mathrm{H}$, defensa de los valores del grupo y ataque a los valores opuestos a ellos. Cuando el $\mathrm{H}$ descortés es refractario al grupo, agrede al oyente porque éste manifiesta afiliación al grupo: Hay simultáneamente, por parte del $\mathrm{H}$, ataque primario a los valores del grupo y defensa implícita de sus propios valores.

Para la descortesía en el debate político cara a cara, tomamos dos entre los ejemplos que Blas Arroyo (2001) ha recogido de los dos debates televisivos Aznar- 
González, representantes parlamentarios de opuestas formaciones políticas españolas, en el contexto de la campaña electoral de 1993. Advertimos que la descortesía aquí presente depende sobremanera de la volición de cada sujeto interviniente, dirigida a incrementar el propio poder, aunque coincidimos con Blas Arroyo (2001: 18) en que el tipo de evento comunicativo y la temática del debate político son favorables a la expresión de esa agresividad. Enfatizamos, empero, que los interlocutores son muy conscientes de que participan de un juego histriónico destinado a aniquilar al adversario, con el fin de captar el favor de la audiencia.

A nuestro juicio, el mutuo reconocimiento de la manipulación atempera paradójicamente la lesión que cada interactuante inflige a la imagen del otro: La certeza de que la descortesía se esgrime como un instrumento para procurar un cierto efecto, mitiga el agravio que igual quantum de agresividad causaría emitido ab imo pectore. El uso de las estrategias de asociar directamente al interlocutor con hechos negativos, imputarle incompetencia o intenciones aviesas, decirle que miente, ridiculizarlo, acusarlo de contradictorio y lo cíclico de esos ataques, en otro contexto conducirían rápidamente al insulto abierto.

Los actores buscan, y a menudo logran, suscitar en la audiencia un sentimiento de victoria para el ofensor y el consiguiente de derrota para el ofendido. Parecieran descartar en la audiencia la reacción normal esperable ante la descortesía en esta cultura: Actitud de rabia hacia el ofensor y de piedad para con el ofendido. La institucionalidad del contexto, el cuidado de la propia imagen ante la audiencia y el diseño estratégico de esta descortesía generalmente la preservan de caer en el insulto.

La acotación de la agresión dentro de un rango de urbanidad tiende a precaver la posible pérdida de imagen ante la audiencia y a evitar la consiguiente pérdida de adeptos entre ella. Ésta es una descortesía de fustigación, pública, esto es, llevada a cabo frente a espectadores, y bidireccional, o sea, caracterizada por la reciprocidad de la actitud y la equipolencia de la intención de los interactuantes. Su fuerte propensión al crescendo, es decir, a que las emisiones descorteses sean las únicas componentes de la relación o las que priman en ella, configura una escalada simétrica, (Watzlawick et alii, 1967) y Pardo (1988).

El P(oder) de cada interactuante (Brown y Levinson, [1978] 1987) ha sido preasignado institucionalmente, con relativa paridad, y el objetivo de cada uno es incrementar la propia cuota y disminuir la del otro; como consecuencia, la D(istancia social) (Brown y Levinson, op.cit.) entre los actores fluctúa durante el intercambio.

Coherentemente con la metodología de análisis, podemos afirmar que, en dicho debate político-electoral, cada interlocutor pugna por mostrar una mayor afiliación al grupo de la audiencia que la de su antagonista, es decir, pugna por erigirse en representante nato de ella. Coexisten la cortesía hacia la audiencia y la descortesía de fustigación, más por refractariedad al grupo político del adversario, que por afiliación exacerbada al propio grupo. Tal descortesía de fustigación procura la supresión del antagonista, presuntamente a propósito de las acciones de éste que puedan derivar en perjuicios para la audiencia.

La faz de cortesía supone el uso por parte del $\mathrm{H}$ de una macroestrategia de argumentación indirecta cortés (Kaul de Marlangeon [1992] 1995-2003) mediante la cual induce al auditorio a adherirse a su enfoque. La oblicuidad del acto estriba en que, si bien cada actor habla para la audiencia, de hecho no se dirige a ella, sino a su interlocutor. 
Para la descortesía en una instrucción militar de reclutas, tomamos tres entre los ejemplos que Culpeper (1996: 359-363) extrae de una entrevista entre una recluta y tres sargentos, uno de ellos mujer, del documental Soldier Girls (Broomfield y Churchill, 1981). Esa descortesía es ejercida por el instructor, sin réplica por parte de la recluta. El instructor es el único que detenta el poder por delegación institucional. Esa unidireccionalidad de la relación está orientada a un fin predeterminado: La aceptación por parte de la recluta de la jerarquía como valor supremo e inherente a esa actividad y su sometimiento a la autoridad, a costa de la pérdida de la propia individualidad y de la autoestima.

Culpeper indica que hay dos razones para la prevalencia de la descortesía en ese discurso: a) la gran desigualdad de poder entre los interactuantes y b) una particular filosofía de adiestramiento, basada en la despersonalización del recluta y su posterior acrisolamiento en el molde del soldado ideal, lo cual implica obedecer órdenes sin dudar ni replicar.

Éste es un tipo de descortesía pública caracterizada por la complementariedad rígida, (Watzlawick et alii, op.cit. y Pardo, op.cit.). Ésta última aparece cuando se abandona la condición de la alternancia: El H que produce la zona de mayor tensión es siempre el mismo en todas las interacciones, sin que el otro $\mathrm{H}$ tenga oportunidad de cambiar de rol.

En la cortesía, $\mathrm{P}$ es una dimensión social asimétrica; es el grado en el cual el $\mathrm{O}$ puede imponer sus propios planes y su autoevaluación, a costa de los planes y de la auto evaluación del H, (Brown y Levinson 1987: 77).

El hecho de que en la instrucción de reclutas la desigualdad sea permanente, lo cual a nuestro entender, es más decisivo que el que sea grande y lo ya dicho acerca de la descortesía presente en tal instrucción, determinan que la variable P sea en este caso constante, una de las posibilidades conceptuales de la variabilidad.

En la cortesía, D es una dimensión social de similitud o diferencia, conforme a la cual $\mathrm{H}$ y O pretenden los propósitos del acto (Brown y Levinson 1987: 76); se manifiesta a través de pautas como la frecuencia de la interacción y el intercambio de imagen .

En la descortesía que campea en la instrucción de reclutas, D proviene de una jerarquía rígida, por lo cual es una medida institucional de diferencia, conforme a la cual el $\mathrm{H}$ pretende los propósitos de su acto. Como dicha diferencia se mantiene invariable, $\mathrm{D}$ también resulta constante, al igual que $\mathrm{P}$.

En sus ataques a la recluta, el instructor trasunta su afiliación exacerbada al grupo que encomienda la instrucción militar, su adhesión consciente y orgullosa a sus miembros y a su ideología. Paradójicamente, el propósito que persigue con su descortesía es promover en la recluta la misma afiliación exacerbada a ese grupo.

En la entrevista referida, la recluta es interrumpida, no se le permite hablar y cuando intenta una defensa, ésta es ignorada. Ello es evidencia del comportamiento de $\mathrm{P}$ y D y de la unidireccionalidad de la descortesía empleada.

Por cuanto precede, es una descortesía de fustigación por afiliación exacerbada del instructor al grupo de sus mandantes.

Para la descortesía en la poética tanguera de la década de 1920 tomamos cuatro de los ejemplos ya consignados en dos trabajos previos (Kaul de Marlangeon [1992] 1995-2003 y 2005a). Ambos se basan en un corpus de aproximadamente 60 letras que más fielmente reproducen la oralidad del lenguaje coloquial urbano de la clase baja. En ese contexto la descortesía se ejerce unidireccionalmente en una esfera de vida privada. 
El reconocimiento de la descortesía como pauta característica del grupo humano estudiado sobreviene como resultado de las constataciones de los comportamientos singulares de sus miembros, cuyas interacciones agresivas tienden a incrementar situacionalmente el poder del $\mathrm{H}$ sobre el $\mathrm{O}$.

En la poética tanguera de este período, uno de los rasgos más sobresalientes es la agresividad en las relaciones sociales, que ocurre por refractariedad del $\mathrm{H}$ hacia su grupo o por afiliación exacerbada del $\mathrm{H}$ a su grupo. Ambas dan lugar a la descortesía de fustigación, característica idiosincrásica de la comunidad representada en el tango.

Para el protagonista masculino del tango, el amor es casi siempre un castigo o un engaño que lo conduce al fracaso; su despecho lo lleva a manifestar reproche, crítica, burla, queja, advertencia, confesión o expresiones de fuertes emociones negativas hacia la mujer que lo traiciona y abandona. Hacia su rival adopta generalmente una postura moralista, rencorosa o irónica. El alejamiento del arrabal por parte del hombre o de la mujer, en procura de ascenso social, es visto como traición de clase.

Dado que la sociedad suministra los parámetros de la cortesía y que la descortesía representa el quebrantamiento consciente y volitivo de dichos parámetros, quebrantamiento que puede ser diferente de $\mathrm{H}$ a $\mathrm{H}$, la descortesía reconoce individualidad. Hablar de la descortesía como pauta característica de un grupo humano, por ejemplo el de los personajes del tango, importa considerar el conjunto de las actitudes descorteses individuales de sus miembros. Por ello interpretamos el yo individual de cada letra de tango, con su relato de experiencias personales, no sólo como un yo individual, sino también como un yo social, portador de una ideología de individuos de extracción marginal cuya estructuración cognitiva ha sido modelada por su condición miserable de vida.

El discurso de la poética tanguera es un claro ejemplo de descortesía en contextos no institucionales, en los cuales la variable $\mathrm{P}$ depende de factores sociológicos-contextuales, Allí los actos de habla descorteses trasuntan una disputa por el poder entre el $\mathrm{H}$ y el $\mathrm{O}$ ficcionales.

La variable $\mathrm{D}$, que en la cortesía está basada en atributos sociales estables, en esta descortesía de esfera privada está basada en factores personales.

Para la descortesía intragrupal crónica en la interacción coloquial de clase media baja del español rioplatense, tomamos un ejemplo de Kaul de Marlangeon (2005b), artículo cuyo corpus está constituido por las obras "Chúmbale", de Viale (2001) y "El patio de atrás", de Gorostiza (1999).Tal descortesía depende sobremanera de la sucesión de situaciones adversas que ha padecido el hablante: Más de sus circunstancias que de su voluntad.

Los actores son instintivos, primarios, virginales. La autenticidad y la espontaneidad en el discurso revelan que la descortesía está destinada a preservar la territorialidad del H, a mantener a raya al O. La exasperación puede elevar el tono de la voz hasta llegar eventualmente al grito o al insulto.

La descortesía es casi connatural por lo vivenciada y consuetudinaria, en un ambiente de permanente fastidio. A ello coadyuva la distancia social exigua o nula entre los interactuantes, por tratarse de personas que tienen un gran conocimiento interpersonal y una gran familiaridad; por ello la descortesía intragrupal crónica se presenta en interacciones simétricas, es decir, de relativa igualdad en términos de P y D, y se orienta fundamentalmente a afectar las imágenes activas privadas de los actores. No siendo institucional el contexto, el $\mathrm{P}$ se construye principalmente por la misma actividad discursiva. 
Hay una multidireccionalidad en esta descortesía, como suma de las múltiples instancias bidireccionales o intercambios descorteses. En cada una de éstas, el $\mathrm{H}$ se arroga poder en defensa de su imagen.

La descortesía lingüística intragrupal marca una relación de individuo versus individuo dentro del mismo grupo, y no de individuo versus grupo. Por tanto, las categorías de descortesía por afiliación exacerbada o por refractariedad no le son de aplicación

Cada interactuante busca la preeminencia de su propio modo de ser, desde una concepción singular, no grupal, de dicho modo, procurando resguardar que su yo no sucumba, aun cuando el precio del resguardo sea el menoscabo o la anulación de los demás. Ello es determinante de la cronicidad de la descortesía en la interacción coloquial del grupo.

En este contexto de ámbito no institucional, la descortesía forma parte del aprendizaje del modus vivendi; cada interactuante tiene expectativas de comportamiento descortés por parte de los demás, aunque no pueda predecir la pauta según la cual han de actuarlo.

\section{Descortesía: Pautas de comparación}

\section{Contextos institucionales:}

\section{-ejercida por un individuo público, en representación de su grupo; -según roles sociales estables}

\section{Contextos no institucionales: \\ -ejercida por un individuo privado, a título personal; -independiente de roles estables}

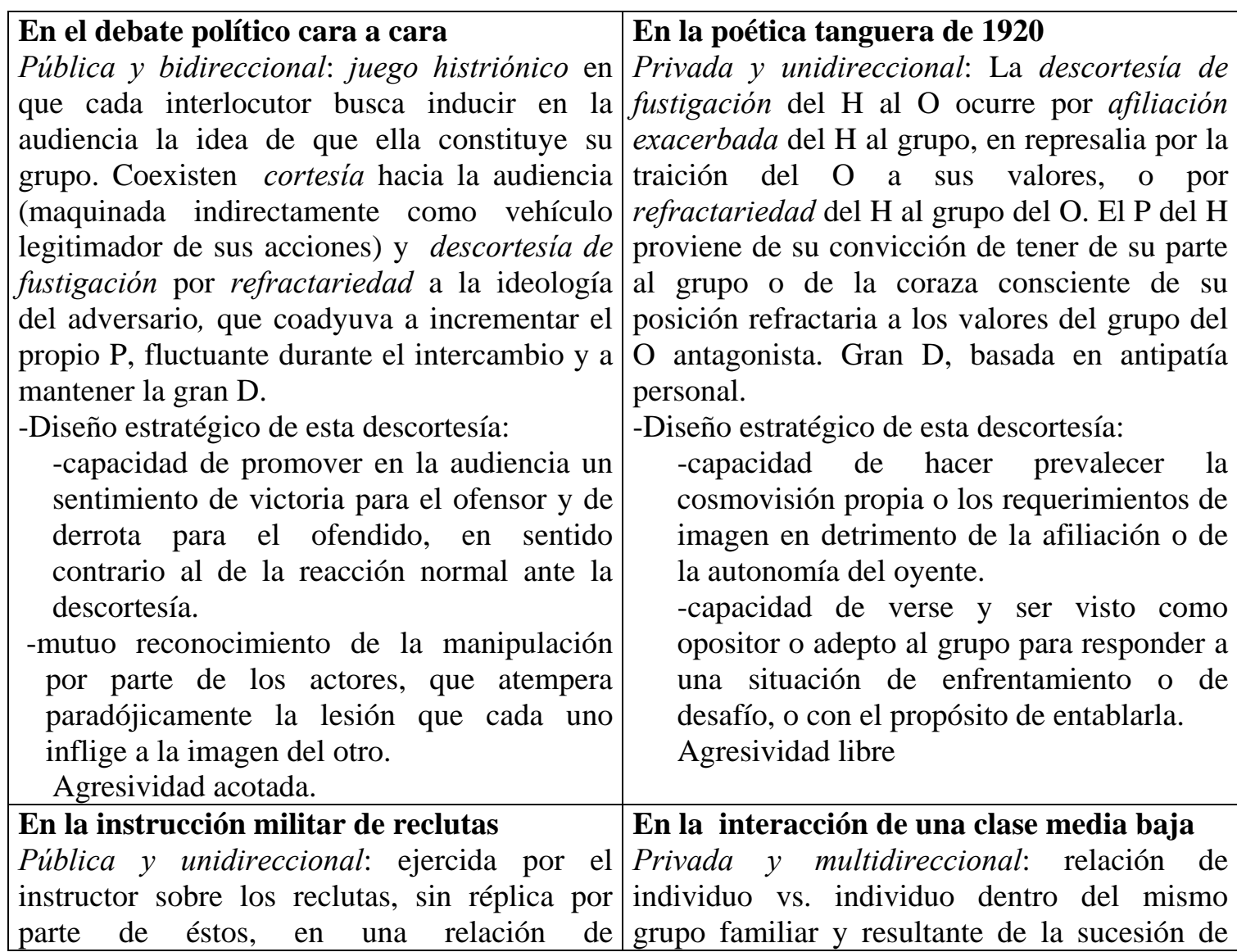




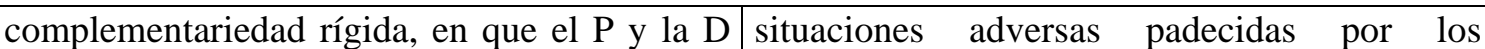
del instructor son constantes, por delegación hablantes. La multidireccionalidad es la suma institucional.

Se trata de una descortesía de fustigación descorteses.

motivada por afiliación exacerbada del $\mathrm{P}$ se construye por la actividad discursiva; instructor al grupo institucional y esgrimida queda sujeto a factores situacionales. D es como técnica de despersonalización de la exigua o nula, en un ambiente de gran recluta.

-Diseño estratégico de esta descortesía:

familiaridad, pero sin intimidad.

-capacidad de infundir en la recluta una -Diseño estratégico de esta descortesía:

afiliación exacerbada al grupo que encomienda la instrucción militar y de aceptar la jerarquía como valor supremo e inherente a la actividad militar.

Agresividad libre. -capacidad de promover la preeminencia del propio modo de ser, desde una concepción singular, no grupal, al precio del menoscabo o anulación de los demás. -parte del aprendizaje del modus vivendi. Agresividad crónica, en general acotada. 


\title{
IMPOLITENESS IN INSTITUTIONAL AND NON-INSTITUTIONAL CONTEXTS
}

\author{
Silvia Kaul de Marlangeon
}

\begin{abstract}
The analysis of impoliteness has mainly concentrated on the relation between text and context itself rather than on the differences between types of contexts. The aim of this study is to compare impoliteness in both institutional and non-institutional contexts. The institutional contexts to be dealt with are: A) face-toface political debate and B) army recruit training. The selected non-institutional contexts are C) the Tango lyrics of the 1920's and D) the interaction among lower middle-class people who speak River Plate Spanish.

In a previous paper (Kaul de Marlangeon 2005a), I proposed the category of fustigation impoliteness by refractoriness or exacerbated affiliation where refractoriness and exacerbated affiliation function as counterparts to Bravo's categories of politeness, autonomy and affiliation. In the present paper and within the theoretical and methodological framework for the study of fustigation impoliteness, I deal with three of the above mentioned contexts A) , B) and C), and the type of fustigation impoliteness that characterises each of them. In my analysis I show that in face-to-face political debate and military recruit training impoliteness is public, bi-directional in the former and unidirectional in the latter. In the Tango lyrics of the 1920's fustigation impoliteness is private and unidirectional. Finally in the context of interaction among lower middle-class people who speak River Plate Spanish, impoliteness is chronic, intra-group, private and multi-directional. For this kind of impoliteness the concepts of refractoriness and exacerbated affiliation do not apply because this impoliteness is about the relationship between an individual versus another individual within the same group rather than an individual versus the group.
\end{abstract}

Keywords: Fustigation impoliteness; Refractoriness; Exacerbated affiliation; Chronic intra-group impoliteness.

\section{Introduction}

The analysis of impoliteness has mainly concentrated on the relation between text and context itself rather than on the differences between types of contexts. My aim in this paper is to compare impoliteness in both institutional and non-institutional contexts.

The institutional contexts to be dealt with are: Face-to-face political debate (Blas Arroyo 2001) and army recruit training (Culpeper 1996). The selected non-institutional contexts are the Tango lyrics of the 1920's (Kaul de Marlangeon [1992] 1995-2003 and 2005a) and the interaction among members of lower middle-class speakers of River Plate Spanish (Kaul de Marlangeon 2005b).

Bravo (see Bravo in this volume and 1999, 2001, 2002, 2003 and 2004) developed the virtual categories of autonomy and affiliation from a socio-cultural perspective, which means that the contents of these categories vary according to the culture involved. Furthermore, she defines these contents in terms of the way an individual perceives himself and is perceived by the others, either as different from the group or as a member of it respectively. 
Also from a socio-cultural point of view and on the assumption that impoliteness, as well as politeness, is a field of research situated at the intersection of language and social reality, I have introduced the concepts of refractoriness and exacerbated affiliation for impoliteness (Kaul de Marlangeon 2005a), as respective counterparts of autonomy and affiliation. Refractoriness and exacerbated affiliation constitute the category of fustigation impoliteness, which is characterized as strategic verbal aggression from speaker to hearer.

Refractoriness is defined as the exacerbated autonomy of considering oneself and being considered by the others as opponent to the group; whereas, exacerbated affiliation involves seeing oneself and being seen by the others as part of the group, with the right to choose impoliteness in its defence.

Within the previously mentioned theoretical and methodological framework, the four contexts selected as data for this study will be described and compared in the next sections. Unlike politeness, which involves parameters provided by society, impoliteness has no pre-established patterns of behaviour. It does represent a conscious and voluntary movement away from those parameters. Because this process varies from speaker to speaker, it can be claimed that individuality is a characteristic feature of impoliteness.

Therefore, to view impoliteness as a typical standard of a group means to consider at the same time the set of individual impolite attitudes and behaviours of its members.

It must be acknowledged that the diverse nature of the selected corpus provided not only the context for the study but also a challenge for testing out my theoretical assumptions.

The two examples used for Context A are taken from those that Blas Arroyo (2001) has collected from two face-to-face televised Spanish debates between Aznar and González, parliamentary representatives of opposite political parties: The Partido Popular (PP) and the Partido Socialista Obrero Español (PSOE), respectively, during the electoral campaign of 1993. The three examples used for Context B are taken from those that Culpeper (1996) has extracted from an interview between a female recruit and three sergeants, one of whom is also a woman, from the documentary Soldier Girls (Broomfield and Churchill 1981), filmed at an American recruit-training base in 1980. The four examples used for Context $\mathrm{C}$ are taken from two previous papers of my own (Kaul de Marlangeon [1992] 1995-2003 and 2005a). The corpus for both of them is a selection of approximately sixty tango songs of 1920, which faithfully represent the oral and colloquial language of the urban low social class. The example used for Context D comes from another article of my own ( Kaul de Marlangeon, 2005 b), whose corpus consists of fragments of two Argentine plays, "Chúmbale" by Viale (2001) and "El patio de atrás" by Gorostiza (1999).

The selected examples illustrate the respective contexts where determinate types of impoliteness occur.

In these contexts I deal with authentic impoliteness rather than non-authentic impoliteness (Bernal in this volume), pseudo-impoliteness (Albelda Marco in this volume) or anti-impoliteness (Zimmerman 2003). Neither do I deal with semi institutional multiple debates, such TV debates (Hernández Flores in this volume or Morales López and Prego Vázquez 2002). 


\section{Fustigation impoliteness}

In a previous paper (Kaul de Marlangeon 2005a), I described what I call fustigation impoliteness, metaphorically as whipping somebody or something. This kind of impoliteness is shown as verbal aggression from a speaker to a hearer, overwhelmingly consisting of voluntary, conscious and strategic behaviour intended to damage the hearer's face, with the purpose of confronting a challenging situation, or of becoming involved with it. The larger part of its acts are on record, since they tend to secure confrontation in discourse.

The concept of refractoriness in impoliteness describes such attitude as diametrically opposed to that of affiliation in politeness, because the person who criticizes, censures, attacks, fights somebody for something wants to place himself in a refractory position with respect to the matter that provokes his opposition.

Besides, when the speaker perceives in the hearer great autonomy with respect to the group or even opposition to it, the speaker's exacerbated affiliation to the group drives him to be impolite towards the hearer.

Therefore, fustigation impoliteness recognizes two essential motivations:

a) exacerbated affiliation to the group,

or

b) refractoriness to the group.

Each one of these motivations can be seen from two perspectives: One defensive and the other one, offensive.

-If the impolite speaker is a follower of the group, he attacks the hearer when he perceives in the hearer an attitude that may range from great autonomy with respect to the group to opposition to it. There is simultaneously, on the part of the speaker, defence of the values of the group and rejection of those that oppose the group.

-If the impolite speaker is refractory to the group, he attacks the hearer when he perceives in the hearer affiliation to the group. There is simultaneously, on the part of the speaker, a primary attack to the values of the hearer's group and an implicit defence of the values of the speaker's group.

\begin{tabular}{|l|l|l|}
\hline & $\begin{array}{l}\text { Politeness (referred to the basic } \\
\text { social face, this one related to } \\
\text { socio-cultural premises) }\end{array}$ & $\begin{array}{l}\text { Impoliteness (determined by } \\
\text { variable individual factors, when } \\
\text { socio-spatial-temporal } \\
\text { coordinates have been } \\
\text { established) }\end{array}$ \\
\hline Affiliation & $\begin{array}{l}\text { The individual perceives himself } \\
\text { and is perceived by the others as a } \\
\text { member of the group }\end{array}$ \\
\hline Autonomy & $\begin{array}{l}\text { The individual perceives himself } \\
\text { and is perceived by the others as } \\
\text { different from the group }\end{array}$ \\
\hline
\end{tabular}




\begin{tabular}{|l|l|l|}
\hline $\begin{array}{l}\text { Exacerbated } \\
\text { affiliation }\end{array}$ & $\begin{array}{l}\text { The individual perceives himself } \\
\text { and is perceived by the others as } \\
\text { follower of the group }\end{array}$ \\
\hline Refractoriness & $\begin{array}{l}\text { The individual perceives himself } \\
\text { and is perceived by the others as } \\
\text { opponent to the group }\end{array}$ \\
\hline
\end{tabular}

Figure 1. Theoretical Epitome of affiliation and autonomy politeness categories (Bravo 1999: 160-164) and exacerbated affiliation and refractoriness impoliteness categories (Kaul de Marlangeon 2005a: 310)

\section{Impoliteness in institutional contexts}

According to Renkema (2004: 253), institutions come into existence to serve as social channelling systems of human behaviour. The concept of institution covers those activities through which individuals construct and maintain society with a certain stability and permanence. An institution is a cultural intermediary between individuals and society as a whole.

As systems of shared knowledge held up by the surrounding culture, institutions convey stability to interpersonal relationship. Thereby individual behaviour is regulated through a system of social roles that participants must hold.

Institutional contexts form part of the large context of culture. Since they occur in particular situations, they are set up by the spatio-temporal frame and the local-sociocultural situation in which the communicative exchange occurs.

The institutional contexts under discussion are restricted to a few members of the context of culture. Impoliteness appears in them as a bounded phenomenon of public nature, performed by individuals that act on behalf of the group sharing the same system of values.

\subsection{Context A: Impoliteness in face-to-face political debate}

Impoliteness, as analysed by Blas Arroyo (2001), depends principally on the volition of each one of the participants, and is used to increase their own power. Nevertheless, I agree with Blas Arroyo (2001: 18) that both this type of communicative event and the political nature of the debate encourage aggression.

It is obvious, however, that speakers, in order to capture the interest of the audience, are conscious of being engaged in a histrionic play with the purpose of overwhelming the adversary. Blas Arroyo (2001: 11) observes that this media show represents a personal attack in disguise.

In my opinion, the mutual recognition of the manipulation paradoxically tempers the damage that each interlocutor inflicts upon the other's face: The certainty that impoliteness is displayed in order to achieve a certain effect mitigates the attack that a similar quantum of aggression would cause if it were inflicted impromptu by an ordinary individual. 
In a different context, the frequent use of strategies which directly associate the interlocutor with negative events, charge him with incompetence, hold that he is lying, or ridicule and accuse him of contradictory behaviour, together with the cyclical nature of these attacks would quickly end up in open insult.

The efficacy of this type of impoliteness is measured by its capacity to promote in the audience a return to the pre-cultural phase of antagonism among human beings that differs little from the attitude of the spectators of a fight, where the opponent that shows the greatest fierceness becomes their favourite.

The interactants seek, and often achieve, to stir in the audience a feeling of victory for the offender and the consequent feeling of defeat for the offended. They seem to reject the expected normal reaction of the audience with regard to impoliteness in this culture: An attitude of anger against the offender and one of pity for the offended. The institutional character of the context, the maintenance of one's own face before the audience, and the strategic design of this impoliteness, generally prevent it from turning into insult.

This represents a bounded aggression within a rank of urbanity whose purpose is to prevent a possible loss of face before the audience and to avoid the consequent loss of followers among it. This is what I call fustigation impoliteness, in the sense of voluntary and conscious behaviour, directed at hurting the interlocutor' s face with the aim of creating a situation of confrontation.

This is a type of public impoliteness, which is bi-directional, that is to say, characterized by reciprocity in the attitude and by equipollence in the mutual intention of the interactants.

Besides, the strong tendency of this type to increase to such an extent that impolite utterances can be the only component of the relationship, or those that predominate, shapes a symmetric escalation (Watzlawick et al.1967; Pardo 1988).

According to Fernández (2000: 112), quoted by Blas Arroyo (2001), the interactant's wish to defeat the antagonist can create in the former the need to destroy the latter. The triumph of the attacker consists in the defeat of his opponent rather than in the ability of the attacker's persuasion.

The power of each interactant (Brown \& Levinson [1978] 1987) has been predetermined institutionally with relative equality and the aim of each interactant is to increase his own quota and to decrease that of the other. Consequently, the social distance (Brown \& Levinson [1978] 1987) between the interactants fluctuates during the exchange.

According to my point of view, each interlocutor fights to show greater affiliation to the audience than the antagonist, that is to say, each interlocutor competes to appear ex officio as a representative of the audience. As can be seen, politeness towards the audience and fustigation impoliteness coexist, rather by refractoriness towards the political group of the opponent, than by exacerbated affiliation to the own group.

In the debate situation, the person who exhibits fustigation impoliteness by refractoriness tries to eliminate the adversary, presumably because the adversary's actions might hurt the audience.

Politeness towards the audience presupposes the speaker's use of a macrostrategy of polite indirect argumentation (Kaul de Marlangeon [1992] 1995-2003). Through this strategy the speaker induces the audience to adopt his point of view. The 
obliquity of the act lies in that: Although each interactant speaks to the audience, in fact, he does not address the audience, but his interlocutor.

With the proviso that everywhere the translation from Spanish into English is of my own, the preceding analysis can be illustrated by means of the following examples (1) - (2), numbered (14) - (15) in Blas Arroyo (2001: 32):

(1) José María Aznar: “y usted se comprometió a exigir responsabilidades y no ha exigido ninguna, usted no tiene credibilidad para exigirle responsabilidades a nadie en ese terreno mientras usted no sea capaz....”

'José María Aznar: and you made a commitment to demand responsibilities, but you have not yet demanded anything, you have no credibility to demand responsibilities to anybody in this field as long as you are not competent...'

(2) Felipe González: “ y es verdad que hay que recuperar el empleo (JMA: risas), sí usted se ríe pero no pero no se reirían esos miles, esos millones de personas que le digo; es verdad que hay que hacer un esfuerzo por recuperar el empleo y por superar la crisis, señor Aznar, pero usted no tiene ninguna fórmula para hacerlo, no sabe cómo hacerlo".

'Felipe González: and it is true that it is necessary to guarantee employment (JMA: laughs), yes, you laugh but, but those thousands, those million persons that I told you about would not laugh; it is true that it is necessary to make an effort to guarantee employment and overcome the crisis, mister Aznar, but you have no formula to do it, you don't know how to do it.'

\subsection{Context B: Impoliteness in an army recruit training}

Culpeper (1996: 359-363) took his data from an interview in which a female recruit and three sergeants, one of whom is a woman, participate.

Impoliteness is exerted and deployed by the trainer, but there is no response on the recruit's part. The trainer is the only person that holds power by institutional delegation. The unidirectionality of the relationship is orientated to a predetermined purpose: The recruit's acceptance of the hierarchy as a supreme and inherent value of army job and the recruit's submission to the authority, at the expense of her own individuality and self-esteem.

Culpeper points out that there are two reasons for the preponderance of impoliteness in army recruit training discourse: a) the great inequality of power and b) a particular training philosophy, based on depersonalising the recruit and subsequently rebuilding the recruit in the mould of the ideal soldier, which involves obeying orders without hesitation.

This is a type of public impoliteness characterized by rigid complementariness (Watzlawick et al. 1967; Pardo 1988). Such rigid complementariness appears when the possibility of alternation is abandoned, so the speaker that produces the greatest tension is the same in all interactions all the time, without the interlocutor having the opportunity to change roles. 
In politeness, power is an asymmetric social dimension; it is the degree to which the hearer can impose his own plans and his own self-evaluation at the expense of speaker's plans and self-evaluation (Brown \& Levinson 1987: 77).

Culpeper finds that, in recruit training, there is great inequality of power. In my opinion, what is significant is the permanent character of inequality rather than the amount of inequality. This feature and the previously mentioned impoliteness in army recruit training turn the variable power into a constant in this case. Indeed, constant is one of the conceptual possibilities of variability.

In politeness, social distance is a social dimension of similarity / difference within which speaker and hearer stand for the purposes of this act (Brown \& Levinson 1987: 76). It is revealed principally through the assessment of the frequency of interaction and the interchange of face as a reflex of social closeness.

The social distance present in army recruit training is the result of a rigid hierarchy; it is an institutional measure of difference, according to which the speaker establishes the aims of his act. As that difference remains invariable, social distance also proves to be a constant, together with power.

In his attacks on the female recruit, the trainer shows his exacerbated affiliation to the group commending the training, his conscious and proud membership in that group and his adherence to army ideology. Paradoxically, the reason for the trainer's impoliteness is to promote in the recruits the same exacerbated affiliation to that group.

In the above-mentioned interview, the woman recruit is interrupted, told not to speak, and when she intends her own defence, her response is ignored. This provides evidence of the functioning of power and social distance and of the unidirectionality of the employed impoliteness.

In summary, this impoliteness results in fustigation impoliteness, due to exacerbated affiliation to the group.

The following three fragments have been taken from Culpeper (1996: 360-361) in order to illustrate my analysis:

(3) S1: running your little mouth again you're the one

PA:

S1: intimidating and threatening my squad leaders...

PA:

S1: bullshit tell that god damn lie to someone

PA: I didn't sergeant

S1: that believes your ass private you've already been

PA:

S1: proven to be a damn habitual liar

PA:

(4) S2: disgrace to the uniform that's what you are Alves a disgrace to be wearing a uniform that you're wearing private nothing but a disgrace to that uniform...

(5) S1: you haven't functioned as a human being I doubt since you were about thirteen you stopped being a member of the human race. 


\section{Impoliteness in non-institutional contexts}

The non-institutional contexts I deal with here include any individual that forms part of these contexts.

In non-institutional contexts, the individuals of a given community do not submit to a pre-established system of social rules. For this reason interpersonal relationships are unstable.

Impoliteness appears as a non-bounded phenomenon of private nature, practised by individuals that act on their own impulse.

\subsection{Context C: Impoliteness in Tango lyrics of the 1920's}

By Tango lyrics of the1920's I understand the words of the Tango songs of that decade. In the corresponding selected examples (Kaul de Marlangeon [1992] 1995-2003 and 2005a) impoliteness is unidirectional in the sphere of private life.

In the community under consideration, impoliteness emerges as a result of confirmation of singular behaviours of its members, whose aggressive interactions tend to increase the power of the speaker upon the hearer as a function of the situation.

In these Tango lyrics, aggression in social relationships is one of the outstanding and typical features. Both, refractoriness towards the group or exacerbated affiliation to it, appear as the reiterative behaviour of individuals and give rise to fustigation impoliteness: An idiosyncratic characteristic of the community represented in this poetry.

For the male protagonist of tango, love is almost always a punishment or a matter of deceit that leads him to pain and frustration; his spite leads him to manifest reproach, criticism, mock, complaint, warning, confession or expressions of strong negative emotions towards the woman that betrays and abandons him. Generally he adopts a moralistic, spiteful, resentful or ironic attitude towards his rival. The protagonist of the song sees the abandoning of the slums by either woman or man as an act of treachery of class, as an attempt at social promotion.

It is worth stating at this point that it is society that provides the parameters of politeness and that impoliteness represents a conscious breaking of the established parameters, therefore the process varies from from speaker to speaker. Impoliteness appears as an individual manifestation. In my view, when impoliteness is considered as a characteristic of a human group, for example, the group of people represented in tango poetry, it represents the individual impolite attitudes of its members as a whole. For this reason, I interpret the particular ego of each tango song, as revealed through the recount of personal experiences, not only as an individual ego, but also as a social ego, which is the carrier of an ideology of marginal individuals whose cognitive structure has been moulded by their miserable condition of life.

The discourse of the Tango lyrics of the 1920's is a clear example of impoliteness in non-institutional contexts, in which power depends on sociologicalcontextual factors. Thus, the impoliteness of the speech acts involved shows a dispute about the power between both the fictional speaker and the fictional hearer. While in politeness social distance is based on stable social attributes, this impoliteness of private sphere is based on personal factors. 
Finally, with reference to the question raised by Culpeper (1996: 354) about the correlation between impoliteness and intimacy, I find that, although the interactants are intimately related, as soon as the speaker produces the impolite utterance, he assumes power over the hearer, whereupon their relationship becomes unequal; indeed, without a claim for power, there is no impoliteness.

Examples (6), (7) and (8) that contain criticisms, insults, reprimands, accusations, reproaches, mocks, complaints and disrespectful or pejorative sayings exhibit fustigation impoliteness by refractoriness towards the present values of the treacherous woman. This woman does not hesitate to abandon the traditional values of her slumbackground, and even her man, in order to obtain the comfort and pleasures typical of the upper class in the city.

(6) Yo me acuerdo: no tenías casi nada que ponerte; hoy usás ajuar de seda con rositas rococó... ¡Me revienta tu presencia, pagaría por no verte! Si hasta el nombre te has cambiado como ha cambiado tu suerte: ya no sos mi Margarita... jahora te llaman Margot! ("Margot”, Flores).

'I remember: you didn't have next to nothing to wear, today you wear silk trousseau with little rococo roses your only presence riles me, I would pay for not seeing you again! you are not my Margaret any more...now they call you Margot!'

(7) Che , madam que parlás en francés y tirás ventolín (dinero) a dos manos, que cenás con champán bien frappé y en el tango enredás tu ilusión.... sos (eres) un biscuit de pestañas muy arqueadas, muñeca brava, ¡bien cotizada!

Sos (eres)del Trianón ... del Trianón de Villa Crespo, Che, vampiresa....ijuguete de ocasión!... (“Muñeca brava”, Cadícamo)

'You, madam that speak in French and throw money away lavishly, that dine with champagne very frappe and in the tango interweave your illusion... you are a biscuit of very arching eyelashes, brave doll, well valued! You are from the Trianon...from the Trianon of Crespo Village You, vamp... an occasion toy!...'

(8) ¡Qué progresos has hecho, pebeta (mujer bonita), te cambiaste por seda el percal! Disfrazada de rica estás papa ( muy elegante) lo mejor que yo vi en carnaval! (“Carnaval”, García Jimenez).

'You have made great progress, pretty girl, You had changed silk for percale 
Disguised as rich woman you are very graceful the best that I saw in carnival!'

In the following example (9), the woman inflicts fustigation impoliteness on the male hearer by her exacerbated affiliation to the group of the young men of the upper class:

(9) Pero ¿no ves gilito (estúpido) embanderado, que la razón la tiene el de más guita (dinero)? Que la honradez la venden al contado y a la moral la dan por moneditas?

Vos resultás, haciendo el moralista, un disfrazao...sin carnaval...; ¡Tirate al río! No embromés con tu conciencia, sos un secante que no hacés ni reír... ( “Quevachaché”, Discépolo).

\author{
'But, you don't see flagged stupid \\ that the richer man has the reason? \\ That honesty is sold in cash \\ and morality is given for small change? \\ When you pretend be a moralist, you are a disguised... without carnival...; \\ Plunge into the river! Don't annoy with your conscience, \\ you are a drying tedious man that don't make even one laugh...'
}

\title{
4.2. Context D: Interaction among members of lower middle-class who speak River Plate Spanish
}

The corresponding examples are concerned with a specific type of impoliteness in noninstitutional contexts: Chronic intra-group impoliteness (Kaul de Marlangeon 2005b). This type of impoliteness is characteristic of the speech community referred to in the title and it is the result of the succession of adverse events experienced by these people. Furthermore, here impoliteness is determined by the circumstances of the speaker rather than by his own will.

The interactants behave instinctively and primitively. The authenticity and the spontaneity of their discourse reveal that impoliteness is destined to preserve the territoriality of the speaker, to keep the hearer in line. Due to exasperation the interlocutors may raise their voices to the point of turning the discourse into yelling and insults.

Impoliteness is almost inherent in this group. It is a kind of behaviour learned in daily experience in an atmosphere of permanent annoyance and frustration. A contributing factor is the meagre or null social distance among interactants, who share interpersonal knowledge and great familiarity. For this reason intra-group impoliteness appears with relative similarity with respect to power and social distance and it is fundamentally oriented to affect the face of the actors. As this context is not an institutional one, power is basically created by the discourse activity itself.

In this type of impoliteness there is multi-directionality, which is the sum of multiple bi-directional impolite instances or impolite exchanges. In each of these, the speaker assumes power in defence of his/her own face. 
Chronic intra-group linguistic impoliteness marks an inter-individual relation within the same family group, resulting from a succession of painful situations experienced by the speakers. There is no relationship between an individual and a group; therefore impoliteness categories by exacerbated affiliation to the group or by refractoriness towards it cannot be applied in this analysis.

Each interactant pursues the pre-eminence of his own view, based on his personal (not group) understanding, trying to prevent himself from collapsing, even though the cost of that protection would result in the lessening or annihilation of the others. This is the distinguishing feature of the chronic aspect of the examined intragroup impoliteness.

The group under analysis only presents familiarity, in the sense of domesticity and informality, but not in the sense of intimacy, because of the absence of mutual good feelings.

According to Wierzbicka (2003: 108-111) intimacy implies closeness; in interpersonal relations closeness has two essential elements: Mutual good feelings and great interpersonal knowledge. In the case under study, despite great interpersonal knowledge, such individuals lack closeness and experience mutual distrust. Nobody has either good faith in the other or thinks highly of the other; hence individuals do not feel confident in entrusting their belongings or in communicating secrets, opinions or vicissitudes. No one considers the other as an honest or faithful friend who will exhibit reliable and expected behaviour.

From a socio-cultural perspective, politeness can be understood as a set of standards resulting from manners which develop in society. These manners vary in society and, especially, with society. For that reason, politeness is part of the process of learning a culture.

In non-institutional fields, there are contexts where impoliteness is also a part of learning the way of life. Then each interactant has expectations of impolite behaviour on the part of the rest, although he is not able to predict in each case the standards upon which the other is going to act.

Example (10) is representative of the colloquial interaction of lower middle-class individuals under analysis. It is extracted from the first act of the Argentine play "Chúmbale" by Viale (2001), in order to illustrate the functioning of chronic intra-group impoliteness.

Enzo, the protagonist, a coffee man, lives with his wife, Mecha, in a modest little room of her parents-in-law's house. This room was given up unwillingly by Quique, Mecha's brother. All are members of a poor social group and they embody a hostile family setting. According to the author's words in the preliminary stage direction: "It is about a proletarian house, one step higher than rabble”.

(10) Enzo- Ocho meses que vivo en esta casa y todavía no conseguí que alguien golpeara antes de entrar...

Quique- Acabala, flaco.

Enzo- ¡No la acabo nada! ¡Usted golpea y se acabó! ¿No se puede tener vida privada aquí?

Quique-¿¿Justo a mí me venís a hablar de vida privada? Desde que te casaste con mi hermana me mandaron a dormir al pasillo. Me afanaste la pieza.

Enzo- A llorarle a Cristo. 
'Enzo- Eight months that I live in this house and still I have not been able to get people knock at the door before entering...

Quique- Stop it, lean.

Enzo- I don't stop anything! You must knock at door and that's over! One can not have private life here?

Quique- Don't talk about private life to me? Since you married my sister, they sent me to sleep in the corridor. You stole me the room.

Enzo-Go some where else to complain!

The reproaches that Enzo and Quique make to each other, tend to protect their respective passive faces; Enzo emphasizes the right to privacy and Quique emphasizes the right to territoriality. Impoliteness, which is part of this reproach, is increased here by the employment of directives without softeners, as "stop it", "you must knock at door and that's over", "Go somewhere else to complain”, that hold up the aggression and are necessary for each interlocutor to assume power over the other. Enzo reveals his illusorily over-estimated personality, which is functional in the context of situation of chronic intra-group impoliteness.

\section{Impoliteness. Patterns of comparison}

\begin{tabular}{|l|l|}
\hline $\begin{array}{l}\text { Impoliteness in institutional contexts } \\
\text { (of a public individual representing a group } \\
\text { and according to stable social roles) }\end{array}$ & $\begin{array}{l}\text { Impoliteness in non-institutional contexts } \\
\text { (of a private individual representing himself/ } \\
\text { herself and disregarding stable social roles) }\end{array}$ \\
\hline
\end{tabular}




\begin{tabular}{|c|c|}
\hline $\begin{array}{l}\text { A) Fac } \\
\text { It is } \\
\text { play i } \\
\text { show } \\
\text { greate } \\
\text { Polite } \\
\text { legiti } \\
\text { fustig } \\
\text { towar } \\
\text { latter } \\
\text { which } \\
\text { to kee } \\
\text { Strate } \\
\text {-Capac } \\
\text { feelin } \\
\text { defeat } \\
\text { oppos } \\
\text { impol } \\
\text {-Mutua } \\
\text { by the } \\
\text { the do } \\
\text { face o } \\
\text { - Bounn }\end{array}$ & $\begin{array}{l}\text { C) Tango lyrics of the 1920's } \\
\text { It is private and unidirectional. } \\
\text { The speaker is motivated either by refractoriness } \\
\text { or exacerbated affiliation which are manifestations } \\
\text { of fustigation impoliteness. } \\
\text { Through this impoliteness, the speaker increases } \\
\text { his power in the private sphere. } \\
\text { The speaker's pretension to endow himself/herself } \\
\text { with power derives from his/her conviction of } \\
\text { having the group of affiliates on his/her side or } \\
\text { from his/her own self-protection against the values } \\
\text { of the antagonistic group. } \\
\text { Great distance based on personal antipathy. } \\
\text { Strategic design of this impoliteness: } \\
\text {-Capacity to give priority to the world view and } \\
\text { the face wants of the speaker over those of the } \\
\text { hearer. } \\
\text {-Capacity to consider himself/herself and be } \\
\text { considered as opponent to the group or follower of } \\
\text { it to respond to or engage in a challenging } \\
\text { situation. } \\
\text {-Free aggression. } \\
\text { D) Interaction among members of lower middle- } \\
\text { class River Plate Spanish speakers } \\
\text { It is private and multi-directional. } \\
\text { Inter- individual relation within the same familiar } \\
\text { group, resulting from a succession of painful } \\
\text { situations experienced by the speakers. } \\
\text { The multi-directionality is the sum of multiple bi- } \\
\text { directional impolite instances. } \\
\text { Power is built through discursive activity and } \\
\text { depends on situational factors. Distance is } \\
\text { exiguous or null in a very familiar setting, without } \\
\text { intimacy. } \\
\text { Strategic design of this impoliteness: } \\
\text {-Capacity to impose his/her individuality over the } \\
\text { individuality of the others, from an individual } \\
\text { rather than group point of view. It is part of the } \\
\text { learning of the way of life. } \\
\text {-Chronic aggression, generally bounded. }\end{array}$ \\
\hline
\end{tabular}

Figure 2. Impoliteness in institutional and non-institutional contexts

\section{Conclusions}

Until recently, the analysis of impoliteness has mainly concentrated on the relation between text and context itself, without resorting to a comparison between types of contexts where impoliteness is involved. In the present paper I have compared the 
institutional and non-institutional contexts that seem to elucidate the functioning of fustigation impoliteness.

My principal claims are the following:

1) In contrast to impoliteness in institutional contexts, non-institutional contexts do not presuppose socially pre-determined roles; the person who exhibits impoliteness, assumes power ipso facto and thus his position as such does not depend on regular social assessments.

2) In both institutional contexts, face-to-face political debate and army recruit training, impoliteness is public; bi-directional in the former and unidirectional in the latter.

3) In both non-institutional contexts, Tango lyrics of the 1920's and the interaction among members of lower middle-class speakers of River Plate Spanish, impoliteness is private; unidirectional in the former and multi-directional in the latter.

4) Concerning fustigation impoliteness in institutional contexts, the purpose of making one's own view of the world prevail has different motivations:

In face-to-face political debate, the speaker's goal is to satisfy a personal ambition; for this reason the aggression is bounded within an urbanity range that protects speaker from possible loss of followers.

In army recruit training, the trainer tries to promote in the recruit an exacerbated affiliation to the group that entrusts the military training and the acceptance of hierarchy as a supreme value inherent in military activity.

5) With respect to fustigation impoliteness in non-institutional contexts, there is an underlying biological, general and diffuse purpose of making one's own view of the world prevail, but there is no personal concern to realize one's own ambition; therefore impoliteness is not bounded within an urbanity range and the aggression scale can turn into insult.

In sum, I have focused my analysis on four contexts of impoliteness, three of which show fustigation impoliteness. Undoubtedly, the analysis of more data from both institutional and non-institutional contexts will provide further interesting insights into this relatively new field of study.

\section{References}

Blas Arroyo, José Luis (2001) "No diga chorradas...” La descortesía en el debate político cara a cara. Una aproximación pragma-variacionista. Oralia 4: 9-46.

Bravo, Diana (1999) ¿Imagen ‘positiva’ vs. imagen ‘negativa’? Pragmática socio-cultural y componentes de face. Oralia 2: 155-184.

Bravo, Diana (2001) Sobre la cortesía lingüística, estratégica y conversacional en español. Oralia 4: 299314.

Bravo, Diana (2002) Actos asertivos y cortesía: Imagen del rol en el discurso académico argentino. In M.E. Placencia y D. Bravo, Actos de habla y cortesía en español. London: Lincom Studies in Pragmatics, pp.141-174.

Bravo, Diana (2003) Actividades de cortesía, imagen social y contextos socioculturales: Una introducción. In D. Bravo (ed.), Actas del Primer Coloquio del Programa EDICE 'La perspectiva no etnocentrista de la cortesía: Identidad sociocultural de las comunidades hispanohablantes'. Stockholms Universitet: Programa EDICE. 
Bravo, Diana (2004) Tensión entre universalidad y relatividad en las teorías de la cortesía. In D. Bravo y A. Briz (eds.), Pragmática sociocultural: Estudios sobre el discurso de cortesía en español. Barcelona: Ariel, pp.15-37.

Brown, Penelope, y Stephen C. Levinson ([1978] 1987) Politeness : Some universals in language usage. Cambridge: Cambridge University Press.

Cadícamo, Enrique (1928) Muñeca brava. In Las letras de tango. Antología cronológica. E. Romano (1990) Rosario: Ed. Fundación Ross.

Culpeper, Jonathan (1996) Towards an anatomy of impoliteness. Journal of Pragmatics 25: 349-367.

Discépolo, Enrique S. (1926) Quevachaché. In Las letras de tango. Antología cronológica.E. Romano (1990) Rosario: Ed. Fundación Ross.

Fernández García, Francisco (2000) Estrategias del diálogo. La interacción comunicativa en el discurso político-electoral. Granada: Método Ediciones.

Flores, Celedonio (1919) Margot. In Las letras de tango. Antología cronológica. E. Romano (1990) Rosario: Ed. Fundación Ross.

García Jiménez, Francisco (1927) Carnaval. In Las letras de tango. Antología cronológica. E. Romano (1990) Rosario: Ed. Fundación Ross.

Gorostiza, Carlos (1999) El patio de atrás . Buenos Aires: Puerto de Palos S.A.

Kaul de Marlangeon, Silvia ([1992]1995, 2003) La fuerza de cortesía - descortesía y sus estrategias en el discurso tanguero de la década del '20. RASAL. 3.3: 7-38. (electronic version http://www.edice.org/Documentos/SKaul.pdf).

Kaul de Marlangeon, Silvia (2005a) Descortesía de fustigación por afiliación exacerbada o refractariedad. In D.Bravo (ed.), Estudios de la (des) cortesía en español. Categorías conceptuales y aplicaciones a corpora orales y escritos. Buenos Aires: Dunken, pp.299-318.

Kaul de Marlangeon, Silvia (2005b) Descortesía intragrupal-crónica en la interacción coloquial de clase media baja del español rioplatense. Eódź Papers in Pragmatics 2005/1: 121-138.

Morales López, Esperanza, and Gabriela Prego Vázquez (2002) Entrevistas electorales en las campañas políticas para la Presidencia del Gobierno de 1996 y 2000. Oralia 5: 203-245.

Pardo, Laura (1988) Nociones psicoanalíticas para el análisis lingüístico. La manipulación verbal del poder. Lenguaje en contexto VI: 37-61.

Renkema, Jan (2004) Introduction to Discourse Studies. Amsterdam - Philadelphia: John Benjamins Publishing Company.

Viale, Oscar (2001) Teatro: Chúmbale, Periferia (Tomo II). Buenos Aires: Corregidor.

Watzlawick, Paul, Janet Beavin, and Don Jackson (1967) Pragmatics of human communication. New York: Norton.

Wierzbicka, Anna (2003) Cross-Cultural Pragmatics, The Semantics of Human Interaction. Berlin New York: Mouton de Gruyter.

Zimmermann, Klaus (2005) Constitución de la identidad y anticortesía verbal entre jóvenes masculinos hablantes de español. In D.Bravo (ed.), Actas del Primer Coloquio del Programa EDICE. Stockholm, CD- ROM, pp.47-59 